\title{
The Right to Freedom of Express Opinions in Public Based on Pancasila
}

\section{Triwahyuningsih}

Universitas Admad Dahlan, Yogyakarta

triwahyuningsih@ppkn.uad.ac.id

DOI: dx.doi.org/10.23917/jtl.v3i1.15682

Submission
Track:
Received:
05 September 2021
Final Revision:
29 September 2021
Available online:
30 September 2021
Corresponding
Author:
Triwahyuningsih
triwahyuningsih@ppkn.uad.ac.id

\section{ABSTRACT}

Freedom to express opinions in public is a human right guaranteed by the 1945 Indonesian Constitution and the Universal Declaration of Human Rights. The concept of human rights originating from the West resulted in its application often causing problems. This problem arises because the values of freedom that are generally upheld in the West are different from the specific values based on the philosophy and way of life in each country. The purpose of this study is to describe how the freedom to express opinions in public is in accordance with the values of Pancasila ideology. This research is normative legal research with a statute approach and a conceptual approach. Using primary and secondary legal materials also analyzed qualitatively descriptively. The results of the study conclude that the right to express freedom in public must be in accordance with the values of Pancasila, which is to fulfill the principle of balance between the rights and obligations of every citizen with the goal of responsible freedom being realized. Rights should not be understood only as claims on others, but also contain an obligation to respect the rights of others. Rights always have implications for obligations. All obligations, like all rights, derive from law, because all obligations are moral imperatives and all moral imperatives arise from law. Its application always upholds the values of divinity, humanity, unity, democracy and aims to realize social justice for all Indonesian people.

Keywords: right of freedom, express opinion, Pancasila 


\section{INTRODUCTION}

The life of human civilization has undergone many developments and one of the things born from the process of human civilization is human rights (Marwadianto, 2020). In the context of human rights, the state is the main legal subject, because the state is the main entity responsible for protecting, upholding, and advancing human rights. In human rights law, the rights holder is an individual, while the duty bearer is the state. The state has three generic obligations related to human rights, namely to respect (obligation to respect), protect (obligation to protect), and fulfill (obligation to fulfill). Individuals on the other hand are bound by an obligation not to interfere with the human rights of other individuals (ibid). The implementation of the rights and obligations of citizens is one indicator of the success of the growth of democratic life. The democratic government system guarantees human rights as well as the rights and obligations of citizens as one of the important elements of democracy in addition to the rule of law.

Yudi Latif in his writings in Harian Kompas said that in an authoritarian political system, the main threat to freedom arises from the state. Whereas in a democratic system, threats come from the forces of society in the form of communalistic fanaticism. Fanaticism is the opponent or enemy of civil society because it rejects rationality, equality of citizenship, and constitutional government as the foundation of democracy. Established groups that experience setbacks and a new middle class whose vertical mobility is hampered often also promote fanaticism by showing an attitude of "hatred" towards freedom, difference and modernization. (Latif, 2020)

The results of the Kompas poll showed that the majority of respondents thought that efforts to protect human rights had not improved. The aspect of expressing freedom was responded positively by respondents, half of the respondents agreed that the freedom of civilians to voice their opinions was guaranteed and protected by the state. However, the issue of freedom of expression still faces challenges during the pandemic. The case of demonstrations completed by chaos and violence related to the rejection of the Job Creation Act is a concrete example. The opinion of respondents is $68.2 \%$ that the party trusted to fulfill human rights, especially freedom of opinion, is the government entirely. (“Perlindungan HAM Jalan Di Tempat,” 2020) 
Meanwhile, a survey conducted by National Commission of Human Rights on Public Views on the Right to Freedom of Opinion and Expression in Indonesia concluded that the majority of respondents felt that there was still room for freedom to criticize the government, at least $29.4 \%$ of the public considered criticizing the government to have the highest level of freedom. There are $52 \%$ who think that the freedom to criticize the government is reasonable, while those who think that it is too free are $18.6 \%$ ("Sebagian Warga Tak Bebas Kritik Pemerintah,” 2020). Kontras revealed that there were several forms of violence by the apparatus in demonstrations against the Omnibus Law of October 8, 2020 and arbitrary actions by the police in disbanding demonstrations, such as arresting demonstrators who were not involved in the attack, violence against medical volunteers, unarmed protesters and non-resistance protesters when arrested, the police attacked PMKRI (Indonesian Catholic Student Association) secretariat in Surabaya (Faizal, 2020). Based on the data above, the question arises how is the freedom to express opinions in public based on the values of Pancasila?

\section{RESEARCH METHOD}

This research is a normative legal research with a statute approach and a conceptual approach by first seeking the views of scholars and legal experts (Marzuki, 2017), the concept was then linked to law no. 9 of 1998 concerning freedom of expression in public and Law no. 39 of 1999 concerning Human Rights. Using primary and secondary legal materials. The descriptive qualitative analysis was compiled in detail, systematically, and continuously, through steps, data reduction, data classification, data interpretation, data display and conclusions.

\section{DISCUSSION}

\section{A. Human Rights and the Right to Express Opinions in Indonesia}

As an independent country that is a member of the United Nations, Indonesia bears the moral and legal responsibility to uphold and implement the Universal Declaration of Human Rights established by the United Nations, as well as various other international instruments regarding human rights that have been 
accepted by the Republic of Indonesia. The Republic of Indonesia recognizes and upholds human rights and basic human freedoms as rights that are inherently inherent in and inseparable from humans, which must be protected, respected, and enforced for the sake of increasing human dignity, welfare, happiness, and intelligence and justice. (UU No. 39 Tentang Hak Asasi Manusia, 1999)

The concept of Human Rights refers to Law no. 39 of 1999 is "a set of rights inherent in the nature and existence of humans as creatures of God Almighty and is His gift that must be respected, upheld and protected by the state, law, government, and everyone for the sake of honor and protection of human dignity."

Freedom of expression is a human right which is one of the basic requirements for the implementation of a democratic government under the Rule of Law (Budiardjo, 2008). These rights are needed to uphold justice and truth, promote public welfare, and educate the nation's life and can support supervision, criticism, and suggestions for the administration of government. ("Standar Norma Dan Pengaturan Hak Atas Kebebasan Berpendapat Dan Berekspresi,” 2021)

The 1945 Indonesian Constitution (hereinafter abbreviated as UUD 1945) Article 28 stipulates that "the freedom of association and assembly, of expressing ideas orally and in writing and so on is stipulated by law.” Article $28 \mathrm{E}$ paragraph (3) regulates the right to freedom of expression. The next regulation is the Law of Indonesia Republic Number 9 of 1998 concerning Freedom of Expressing Opinions in Public (hereinafter abbreviated as Law on Freedom of Expressing Opinions in Public). Everyone has the right to express opinions in public, including the right to strike in accordance with the provisions of the legislation. (UU No. 39 Tentang Hak Asasi Manusia, 1999)

Freedom to express opinions in public is defined as "the right of every citizen to express his thoughts orally, in writing, and so on freely and responsibly in accordance with the provisions of the applicable laws and regulations in front of many people, or other people, including in a place where the visited and or seen by everyone" (UU No. 9 Tentang Kemerdekaan Menyampaikan Pendapat Di Muka Umum, 1998). Included in the delivery of opinions orally are speeches, dialogues, and discussions. In writing, these include petitions, pictures, pamphlets, posters, brochures, leaflets, and banners. As for 
what is meant by "and so on" such as, silence and hunger strikes. Various forms of delivery can be made, such as through demonstrations; parade; general meeting; and or free pulpit, which is conducted in places open to the public, except: within the presidential palace, places of worship, military installations, hospitals, airports or harbors, train stations, land transportation terminals, and national vital objects; and must not be conducted on national holidays and prohibited from bringing objects that can endanger public safety. (ibid)

In conveying it must maintain (1) a balance between rights and obligations; (2) through deliberation and consensus; (3) the principle of legal certainty and justice; (4) must be proportional, namely putting all activities in accordance with the context or purpose of the activity, whether conducted by citizens, institutions, or government officials, which are based on individual ethics, social ethics, and institutional ethics (5) benefit principle. (UU No. 9 Tentang Kemerdekaan Menyampaikan Pendapat Di Muka Umum, 1998)

Freedom to express opinions in public needs to be regulated in laws and regulations with the aim of (a) that responsible freedom can be realized as one of the implementations of human rights in accordance with Pancasila and 1945 Constitution; (b) the existence of legal protection in expressing opinions; (c) participation and creativity of every citizen can develop as an embodiment of rights and responsibilities in democratic life; (d) able to balance social responsibility in the life of society, nation and state, without neglecting the interests of individuals or groups. (UU No. 9 Tentang Kemerdekaan Menyampaikan Pendapat Di Muka Umum, 1998)

"In line with the objectives above, legal signs must have autonomous, responsive characteristics and reduce or leave repressive characteristics. By adhering to these characteristics, the Law on Freedom of Expressing Opinions in Public is a statutory provision that is regulative in nature, so that on one hand it can protect the rights of citizens in accordance with Article 28 of 1945 Constitution, and on the other hand, it can prevent pressures, both physical and psychological, that can reduce the spirit and meaning of the openness process in the formation and enforcement of laws."

The right of citizens to express opinions in public can express their thoughts freely, namely to express opinions, views, desires, or feelings that are free from physical, 
psychological, or restrictions that are contrary to the objectives and obtain legal protection including security guarantees. The obligations and responsibilities of citizens in expressing opinions in public must: (a) respecting others’ rights and freedoms, namely to participate in maintaining and safeguarding the rights and freedoms of others to live in a safe, orderly and peaceful life; (b) respecting generally recognized moral rules, meaning respecting religious norms, decency, and politeness in people's lives; (c) obeying the laws and provisions of applicable laws and regulations; (d) maintaining and respecting security and public order means actions that can prevent harm to public peace and safety, both concerning people, goods and health; (e) maintaining the integrity of the unity and integrity of the nation is an act that can prevent the emergence of hostility, hatred or humiliation towards ethnicity, religion, race, and between groups in society. (UU No. 9 Tentang Kemerdekaan Menyampaikan Pendapat Di Muka Umum, 1998)

Albert Hasibuan describes those human rights are understood as one unit and cannot be separated. This understanding shows that in the end there is only one right, namely "the right to be human." Human rights according to Pancasila and 1945 Constitution are “enlightened”, about humans. Jacques Maritain in his writings “The Rights of Man", that "human rights are owned by a person because of the fact that he is a human being.” (ibid)

The obligations and responsibilities of government officials in the implementation of public expression of opinions by citizens, as regulated in Article 7 and its Elucidation (Law No. 9 of 1998) include protecting human rights; respect the principle of legality; respect the principle of the presumption of innocence; and provide security. On point D what is meant by "managing security" is all efforts to create safe, orderly and peaceful conditions, including preventing disturbances or pressures, both physical and psychological from anywhere. (ibid)

\section{B. Rights and Obligations of Citizens in the context of the Rule of Law}

Article $28 \mathrm{~J}$ of the 1945 Constitution states that "In exercising their rights and freedoms, everyone is obliged to comply with the restrictions established by law for the sole purpose of guaranteeing recognition and respect for the rights and freedoms of others and to fulfill fair demands in accordance with morals, religious values, security and public order in a democratic society.” It means that the regulation of rights and freedoms is not 
a goal, but a means to realize a higher-level goal, namely the ideals of the Republic of Indonesia within the framework of Pancasila and the 1945 Constitution. As stated by Sudikno:

"The law is not a goal, but a means or a tool to achieve non-juridical goals and develops due to stimuli from outside the law. Factors outside the law that make the law dynamic. That the law regulates legal relations. The legal relation consists of the ties between the individual and society and between the individual himself. These ties are reflected in rights and obligations. There are various ways of managing these relations. In criminal law, most of the regulations consist of obligations. On the other hand, law often formulates certain events which are conditions for the emergence of legal relations. In its efforts to regulate, the law adjusts individual interests with the interests of society as well as possible. This means trying to find a balance between giving freedom to individuals and protecting society against individual freedom. If there is a conflict in society then the law tries to resolve this conflict as well as possible."

Law as a collection of rules or principles has content that is general and normative, general because it applies to everyone and normative because it determines what should be done, or must be done and determines how to implement compliance with the rules. In Dutch literature the law is called “objectief recht”, objective because it is general, binding on everyone. The word "recht" in Dutch legal language is divided into two, namely: "objectief recht" which means law and "subjectief recht" which means rights and obligations. (Mertokusumo, 2008)

Legal relations are reflected in the rights and obligations given by law. The order created by the new law becomes a reality if legal subjects are given rights and burdened with obligations. Every legal relation created by law always has two aspects, which are rights on the one hand, and obligations on the other. There are no rights without obligations, on the other hand there are no obligations without rights. (ibid)

A citizen carries out the rights and obligations according to his position, at least covering aspects: (1) norms related to the position of a citizen in society, namely regulations that guide a person in social life; (2) what individuals in society as an organization can do; (3) individual behavior that is important to the social structure of society. (Soekanto, 2000) 
"That the rights and obligations of citizens arise or originate from the state. It means that the state gives or imposes these rights and obligations on its citizens. The grant/charge is stated in the legislation so that citizens and state administrators have a clear role in the application and enforcement of these rights and obligations.” (Yasin, 2009)

The importance of social ethics regarding rights and obligations as stated by Bernrd L. Tanya "Rights should not be understood only as claims on others, but also contain an obligation to respect the rights of others. Rights always have implications for obligations. My right to own implies my obligation to respect the property rights of others. My right to be free implies my obligation to respect the freedom of others. The key word is shared responsibility."

Rights play an important role in the position of humans in the life of the state because humans are legal subjects. K. Barents, rights are claims made by one person or group against another or against society. People who have rights can demand that others will respect those rights. Therefore, a right is a legitimate claim or a justifiable claim. Because, simply saying a claim is clearly not enough. It turns out that in our lives we often find claims that cannot be justified. Meanwhile Theo Huijbers, in a broad sense, rights are in the form of an invitation, which is called a sense of generosity, mercy and others. For instance, rights that arise on the basis of mutual love. Whereas in a narrow sense, according to him, rights are in the form of absolute demands that cannot be contested. For instance, the right if someone lives in a dangerous situation.

The components of a right mainly lie in the person, independence and responsibility. Only individuals who are given freedom and obligation by the moral law can have rights. Creatures that act spontaneously and without independence or without responsibility do not need this right (Erwin, 2011).

Meanwhile, Franz Magnis Suseno explained that something is my right, if I can demand that something be given to me and if someone else is obliged to give what I demand.

Rights are normative elements that function as behavioral guidelines, protect freedom, immunity and guarantee opportunities for humans to maintain their dignity. (Demokrasi, Hak Asasi Manusia \& Masyarakat Madani, 2000). According to Bartens, a right can be limited because of a conflict between rights or overpowered by other rights. This means that these rights are limited because other people also have rights, resulting 
in a person's freedom rights are never absolute. According to Tan Malaka, a legal review of the limitation of human rights can be carrieed out by looking at the universe, namely separating the positive and negative as well as attractive and rejecting. In the end, the two greatest natures that move the souls of all living, so also the human soul. First, the will to live, second, the will not to die. If the first will we mention is positive, then the second is negative. If in general the human desire embraces the former, then this means that he also desires to reject the latter. (Malaka, 2000)

When did that right lose? In the reciprocal relationship between rights and obligations, there is a "correlation theory” adopted by utilitarian circles, everyone’s rights are related to the obligations of others to fulfill these rights. "Rights that do not have obligations that correspond to them will be lost” (Erwin, 2011). Ethicists say that most rights are prima facie or rights at first glance, meaning that they are valid until they are overpowered by other, more powerful rights. It means that if right has been defeated by another right then that right will be lost. (ibid)

Not every power in society can be called a right, but only certain powers, namely those given by law to a person. Fitzgerald, mentions the characteristics inherent in rights, according to law are as follows: (a) The right is attached to someone who is called the owner or subject of the right. The person who has the title of the item that is the object of the rights. (b) The right is directed to another person, namely the holder of the obligation. There is a correlation between rights and obligations. (c) The rights that exist in a person oblige the other party to do (commission) or not to do (omission) an act, which is the content of the right. (d) The commission or omission concerns something that can be called the object of the right. (d) Every right according to the law has a title, namely a certain event which is the reason for the attachment of the right to the owner. (Rahardjo, 2006)

The characteristics of the above rights according to Salmond are rights in the strict sense or in stricto sensu. According to him, there are other meanings, namely: independence, power and immunity. Satjipta Rahardjo gave a brief description of this right as follows:

"If the right (in the narrow sense) belongs to someone as a partner of the obligations imposed on others, then the freedom granted by law to me is coupled with the absence of legal obligations to myself. This freedom consists of the 
various interests that are in me to do the things I enjoy or want to do. I can do these things without being hindered by the law. Therefore, the scope of my independence according to the law is as wide as the field of activity which is permitted by law to be carried out. I have the right to do whatever I like, but I do not have the right to do anything that would interfere with the same rights that other people have. So, the first right in a narrow sense relates to the things that other people have to do for me. Whereas freedom according to law here, the right only deals with the things that are allowed to be carried out for myself.”

Power shows characteristics similar to freedom and different from rights in a narrow sense, because it does not have a partner in the form of obligations to others. This power is in the form of a right given to a person to go through legal means to realize his will to change his rights, obligations, responsibilities or other legal relationships, both from himself and others. The definition of rights is also used in the sense of immunity from the legal power of others. This immunity is a liberation from the existence of a legal relation to be changed by others. (ibid)

Curson classifies rights as follows: (1) Perfect and imperfect rights. Perfect rights are those that can be exercised through law as if necessary, through legal coercion. Imperfect rights are those that are recognized by law, but are not always exercised by the courts, such as rights that are limited by institutions that expire. (2) Primary and additional rights. The main right is that which is extended by other rights. Additional rights are complementary to the main rights, such as a land lease agreement which gives additional rights to the main rights of the land owner. (3) Public and civil rights. Public rights are those that exist in society in general, namely the state. Civil rights are those that exist in individuals, for instance the right of a person to enjoy the goods he owns. (4) Positive and negative rights. Positive rights demand positive actions from the party to whom the correlative obligation lies, such as the right to get personal benefits. (5) Property and personal rights. Property rights relate to goods owned by a person that can usually be transferred. Personal rights relate to a person's position which can never be transferred.

The concept of "obligation" as written by a moral philosophy writer W. Poespoprodjo, subjectively, obligation is a moral requirement to do or not do something. Objectively, obligations are things that must be done or not done. The difference between the two is seen in the sentence, "He is obliged", which means: morally he is obliged. And "he does his obligation", meaning: he does something that he must do. 
"Obligation is a passive form of responsibility. Something that is carried out of responsibility is an obligation. Obligation does not take into account profit or return. It is carried out because of the demands of conscience, not because of considerations of the mind. It is an exclamation from within man. The question is, how do we know that something is an obligation? The phrase that reads: "We should do this and that", is a sign that such and such is an obligation.”

According to W. Poespoprojo, all obligations, like all rights, originate from law, because all obligations are moral imperatives and all moral imperatives arise from law. The obligation is imposed by law, which according to its understanding is in accordance with common sense and for the common good. The intention is not to oppress people with unreasonable burdens regardless of the intended good. The valid reasons for being free from obligation are when something is practically impossible and/or the difficulty is out of balance. Obviously, no one can do the impossible. But the difficulty which is intrinsic to duty in itself is never a reason for exemption from duty, for otherwise there would be no obligation. (Erwin, 2011)

\section{The Right to Express Opinions in Public Based on Pancasila}

The values of Indonesian identity are formulated in Pancasila as the philosophy and view of life, the direction of unity and struggle and the nation's personality (Latif, 2015). Pancasila is ideally used as the principle of human civilization and the Indonesian nation. In the midst of increasingly widespread global pressures that contain the potential for dehumanization, Indonesia should be able to make creative selection and synthesis between global vision and local wisdom, between national interests and global benefits, by prioritizing a settlement framework based on the principle of "win-win solution” and rights-based development. (Latif, 2012)

Pancasila serves as the nation's ideology, way of life and the basis of the state. As citizens, we must obey the law that reflects the values of Pancasila as the basis of the life of the nation and state. The rights and obligations of citizens are carried out in accordance with the applicable laws and regulations, including the right to express opinions in public. Genealogically, Pancasila, as said by Kleden, was born as a historico-political gentlemen agreement on how to live in "Rumah Indonesia". Our honor and dignity lies in our firmness to honor our pledge of allegiance or "Pacta sunt servanda" as Indonesian citizens who are loyal to the values of Pancasila. (Tanya et al., 2015) 
The first precept, Belief in the One Supreme God implies that in carrying out the rights and obligations of citizens, they must present God, all religious/belief groups are equally practicing the glory of God, namely doing what is right, what is good and what is noble. The second precept, just and civilized humanity means that human dignity is respected, civilized ways and life are put forward, barbarity and barbaric behavior are avoided, and able to act fairly according to the principles of justice. The third precept, Unity of Indonesia implies that it is based on divine and human values to realize Indonesian unity for all components of the nation. The fourth precept, on the basis of the noble spirit of the first precept, the normative imperative of the second precept and the spirit of unity of the third precept to work together in wisdom and consensus in managing the State to serve the interests of the people, so that the right to freedom of expression in public is respected as long as it is respected. On the other hand, the state is solely to serve the interests of society as a whole. The fifth precept, based on the values of precepts 1 to 4, aims to realize the fifth precept, justice for all Indonesian people with the spirit of carrying out all that is right, fair and good. (ibid)

\section{CONCLUSION}

Recognition of the right to freedom of express opinion has been regulated in the constitution since the emergence of this country. These rights must fulfill the principle of balance between the rights and obligations of every citizen with the aim that responsible freedom can be realized as one of the implementations of human rights in accordance with Pancasila and the 1945 Constitution. Rights are normative elements that function as behavioral guidelines, protect freedom, immunity and guarantee opportunities for humans to maintain their dignity. All obligations, like all rights, derive from law, because all obligations are moral imperatives and all moral imperatives arise from law. It is only in a democratic rule of law that it is possible to recognize the rights of citizens. In the implementation of expressing opinions in public, it must not conflict with the values of Pancasila, which are to present God, to practice the glory of God, namely to do what is right, what is good and what is noble; human dignity is respected, civilized ways and life are put forward; on the basis of the noble spirit of the first precept, the normative imperative of the second precept and the spirit of unity of the third precept to work 
together in wisdom and deliberation solely to realize social justice for all Indonesian people.

\section{REFERENCES}

Faizal, A. (2020). Kontras Ungkap 7 Bentuk Kekerasan Polisi di Demo UU Cipta Kerja di Surabaya. Retrieved April 29, 2021, from kompas.com website: https://regional.kompas.com/read/2020/10/14/20292061/kontras-ungkap-7-bentukkekerasan-polisi-di-demo-uu-cipta-kerja-di-surabaya?page=all

Manan, B. (Ed.). (1996). Kedaulatan Rakyat, Hak Asasi Manusia dan Negara Hukum (Cetakan-1). Jakarta: Gaya Media Pratama.

Tanya, Bernard L. (2011). Politik Hukum: Agenda Kepentingan Bersama. Yogyakarta: Genta Publishing.

Tanya, B. L., Parera, T. Y., \& Lena, S. F. (2015). Pancasila Bingkai Hukum Indonesia. Yogyakarta: Genta Publishing.

Suseno, F. M. (1999). Etika Politik: Prinsip-Prinsip Moral Dasar Kenegaraan Modern. Jakarta: Gramedia Pustaka Utama.

Yasin, J. (2009). Hak Azasi Manusia Dan Hak Serta Kewajiban Warga Negara Dalam Hukum Positif Indonesia. Syiar Hukum: Jurnal Ilmu Hukum, 11(2), 147-160. https://doi.org/https://doi.org/10.29313/sh.v11i2.541

Anonim. (2015). Hak Dan Kewajiban Warga Negara Indonesia Dengan UUD 45. Retrieved from www.mahkamahkonstitusi.go.id website: https://www.mkri.id/index.php?page=web.Berita\&id=11732\#

Barents, K. (2001), Etika, Jakarta: Gramedia Pustaka Utama.

Standar Norma Dan Pengaturan Hak Atas Kebebasan Berpendapat Dan Berekspresi. (2021). Retrieved February 24, 2021, website: www.komnasham.go.id

Sebagian Warga Tak Bebas Kritik Pemerintah. (2020). Kompas.

Pattisina, E. C. (2020). Sebagian Masyarakat Merasa Tidak Bebas Mengkritik Pemerintah. Retrieved from https://www.kompas.id website: https://www.kompas.id/baca/polhuk/2020/12/15/sebagian-masyarakat-merasatidak-bebas-mengkritik-pemerintah/

Marwadianto, M. (2020). Hak Atas Kebebasan Berpendapat dan Berekspresi. Jurnal HAM, 11(1), 1-25.

Budiardjo, M. (2008). Dasar-Dasar Ilmu Politik, Jakarta: Gramedia Pustaka Utama.

Erwin, M. (2011). Filsafat Hukum: Refleksi Kritis terhadap Hukum, Jakarta: Raja Grafindo Persada.

Huda, M. (2017). Ilmu Negara (Cetakan ke-9). Depok: Rajawali Press.

Marzuki, P. M. (2017). Penelitian Hukum. Jakarta: Kencana.

Rahardjo, S. (2006). Ilmu Hukum (Cetakan ke). Bandung: PT. Citra Aditya Bakti. 
Soekanto, S. (2000). Sosiologi Suatu Pengantar. Jakarta: Grafindo Persada.

Mertokusumo, R. M. S. (2008). Mengenal Hukum: Suatu Pengantar. Yogyakarta: Liberty.

Malaka, T. (2000). Dari Penjara ke Penjara. Jakarta: Teplok Press.

Huijbers, T. (1990). Filsafat Hukum. Yogyakarta: Kanisius.

Jakarta, T. I. U. (2000). Demokrasi, Hak Asasi Manusia \& Masyarakat Madani. 199. Jakarta: ICCE UIN.

Undang-Undang Dasar Negara Republik Indonesia. , (1945).

UU No. 39 tentang Hak Asasi Manusia. , (1999).

UU No. 9 tentang Kemerdekaan Menyampaikan Pendapat di Muka Umum. , (1998).

Poespoprodjo, W. (1999). Filsafat Moral: Kesusilaan dalam Teori dan Praktek. Bandung: Pustaka Grafika.

Latif, Y. (2012). Negara Paripurna: Historisitas, Rasionalitas, dan Aktualitas Pancasila. Jakarta: Gramedia Pustaka Utama.

Latif, Y. (2015). Revolusi Pancasila. Bandung: Mizan.

Latif, Y. (2020). Kebebasan dan Kecemasan. Kompas, p. 1.

Latif, Y. (2020). Perlindungan HAM Jalan di Tempat. Kompas, p. 4.

Perlindungan HAM Jalan di Tempat. (2020). Kompas, p. 4. 